\title{
Fish fauna of peatland waters in the middle Mahakam, Kutai Kartanegara, East Kalimantan, Indonesia
}

\author{
Iwan Suyatna ${ }^{1, *}$, Komsanah Sukarti ${ }^{1}$, Henny Pagoray $^{1}$, Arif Data Kesuma ${ }^{2}$, Tunggul \\ Butarbutar $^{2}$, Muhammad Raafi ${ }^{1}$, Muhammad Bagja Britania Suyatna ${ }^{1}$ \\ ${ }^{1}$ Hydrooceanography laboratory and Aquaculture Department, Faculty of Fisheries and Marine \\ Science, Mulawarman University, 75116, Kalimantan Timur, Indonesia \\ ${ }^{2}$ GIZ (Deutsche Gesellschaft für Internationale Zusammenarbeit) East Kalimantan Forestry Agency \\ Office, East Kalimantan, Indonesia
}

\begin{abstract}
A field study was carried out to collect fish from the lake and streams/rivers around the peatland from December 2020 to February 2021. Fishing gears such as gillnet, snakehead pole and line, lift net, trap net ("sawaran", "julu"), and fish pot ("tokong", "pangilar", "bubu" or "lukah" and "tempirai") were operated. Sampling sites, water velocities, and water depth were measured using GPS Garmin 60 CSX, current meter hydrologic velocity meter, and fishfinder Portable, respectively. Generally, water velocities of streams measured were much more rapid than the lakes ranging between $0.33 \mathrm{~m} / \mathrm{s}$ (at water depth: $4.20 \mathrm{~m}$ ) and $0,69 \mathrm{~m} / \mathrm{s}$ (at water depth: $6.80 \mathrm{~m}$ ); and "not detected" (at water depth: $2.40 \mathrm{~m}$ ) and $0.34 \mathrm{~m} / \mathrm{s}$ (at water depth: $1.20 \mathrm{~m}$ ) respectively. Of 7,377 fish samples, there were 50 species discovered belonging to 19 families. Cyprinidae was the most populated in individuals and species as well (1,022 Ind.; 21 taxa). It was followed by Bagridae (63 Ind.; five taxa), Channidae (53 Ind.; three taxa), Clariidae (10 Ind.; three taxa), Siluridae (403 Ind.; three taxa), while other families had just one taxon. Diversity was observed higher in streams (35 species) than lakes (30 species). Local fishers are still performing unselective fishing for feeding fish cage culture.
\end{abstract}

\section{Introduction}

Peatland in the middle Mahakam of Kutai Kartanegara of East Kalimantan covers 18,000 $\mathrm{km}^{2}$ between $180 \mathrm{~km}$ and $375 \mathrm{~km}$ upstream of the mouth of the Mahakam River [1] represents important freshwater swamps. According to [2], this natural resource holds biodiversity and controls flows and floods, while [3] functions as principal breeding grounds and fish sources for domestic consumption and export. Unfortunately, people living in the vicinity caused many adverse effects, particularly water quality [1]. Since the early 1980s, the middle Mahakam and its floodplain areas have been continuously threatened by industrial agriculture and extraction of minerals such as mono-crop/oil palm

*Corresponding author : iwansuyatna123@gmail.com 
plantation (considered the principal agents of deforestation) and coal mining [4]. Consequently, many coal and other materials spill during transportation, deposit, and distribute along the river, causing water to become more turbid and shallower. [5-7] identify that the activities of oil palm plantation and mining increase sediment load in water and pollution. According to [8], coals in water may pollute 20 potentially hazardous trace elements (PHTEs) of heavy metals. [9] investigated the level of 10 heavy metals in water and fish for nine samples from 18 sampling sites downstream of Mahakam River and coastal water. One of 10 heavy metals investigated, leaving the 1 of iron $(\mathrm{Fe})$ in water and the body of other fish, was higher than the allowable limit of both national and international standards. In general, metal concentrations were found much greater in fish and, therefore, might disturb themselves and be unsafe to consume.

In the middle of Mahakam, some indigenous freshwater fish species are endemic, such as Long pectoral-fin minnow Macrochirichthys macrochirus [10]. However, such species have insufficient attention. They are still threatened endangered due to the degradation of wetlands in the middle of Mahakam that is continuing rapidly and the regional economic development.

[11] worked on fish identification for eight years from 1980 to 1987. He recognized 147 indigenous freshwater fish from the middle Mahakam and floodplain areas characterized by slow-flowing and faster-flowing rivers, lakes, small water bodies, and swamps. Four years later, [12] performed similar work in the same areas, and only 82 fish species were identified. And therefore, urged surveys are needed to provide updated data. The present study aimed to know the fish diversity of peatland water of the middle Mahakam, Kutai Kartanegara district, East Kalimantan, and its environmental quality.

\section{Materials and methods}

\subsection{Study location}

Study locations were situated in lakes and streams. The study started a pre-survey in December 2020 to decide the locations and sampling sites before executing the main survey to collect fish and water samples. The locations and sampling sites were recorded by GPS 60S (Fig. 1). Surveys were performed throughout three periods: 1-4 January, 19-22 January, and 13-16 February 2021.

\subsection{Fish and water samples collection}

Fish were collected from lakes and streams/rivers in the middle Mahakam by using various gears such as gill net (local people called with rengge), snakehead pole and line (awai), lift net (anco), trap nets (sawaran, julu), and fish pots (tokong, pangilar, bubuhati, bubu bambu or lukah, bubu paralon and tempirai)(Fig.2). After numbering and separating fish collected from each gear in sites, the fish were placed in the cool box for transport to the laboratory. In location, the water sample was taken directly from the body of water by applying a five liters plastic jerry can without any preservative addition and then put inside the cool box before bring to the laboratory for analysis purposes. The number of water samples was 18 during the whole study. 


\subsection{Water velocities and depths}

Water velocities and water depths were measured in situ using water checker AZ and current meter hydrologic velocity meter and portable fish finder, respectively.

\subsection{Data analysis}

At the laboratory, fish were identified referring to the field guide book of [13-16], similarly to the study reports of [17-19]. On the fish measuring board, fish were photographed by the camera Nikon Coolpix, the size distribution of length and weight were measured by caliper and Krisbow digital precision scale. The analysis of water samples followed APHA Procedure (1998), while the guideline indicating the concentrations of physical-chemical parameters and levels of heavy metals refer to the regulation of the Local Government of East Kalimantan No.: 02 the Year 2011 and the regulation of the Government of the Republic of Indonesia No.: 82 the Year 2001, both on Water Quality Management and Water Pollution. The Palaeontological Statistics (PAST) version 3.0 [20] calculated fish diversity index for explaining fish structure community, map of the study was realized by the Map INFO version 10.0, and we made by hand catch rate or an individual number of fish in an hour as CPUE for all fishing gears.

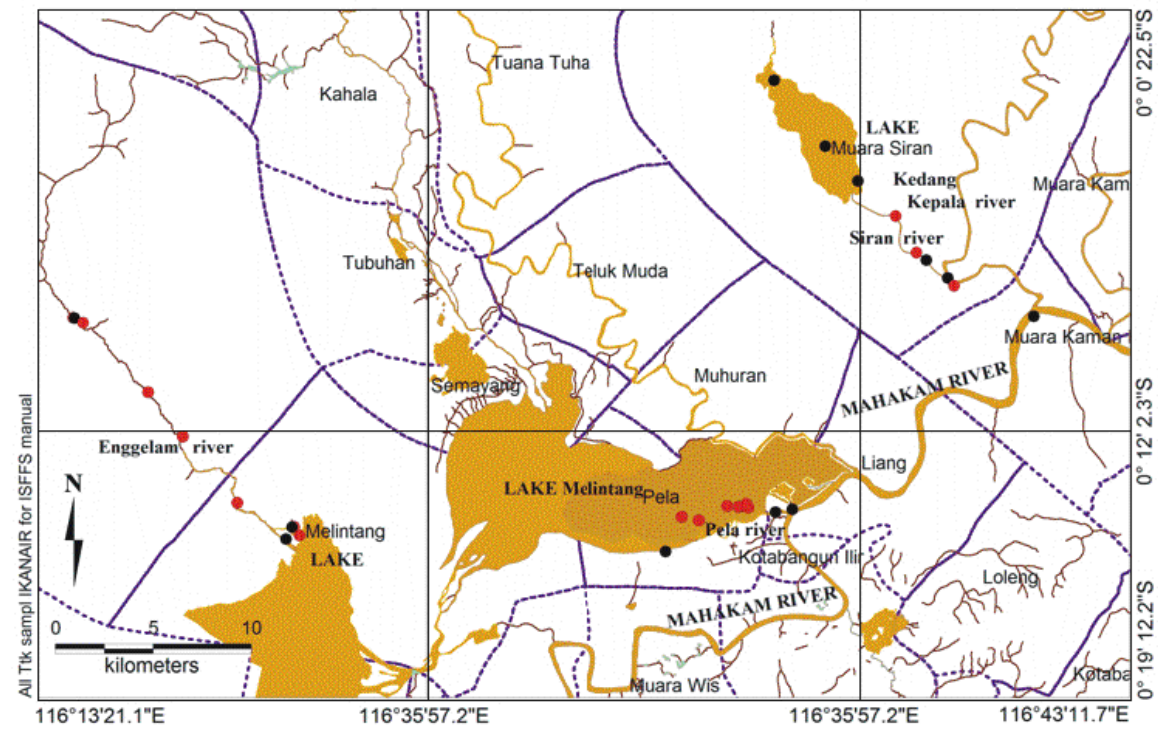

Fig. 1. The distribution of the sampling (measuring) sites of the study in the middle Mahakam, Kutai Kartanegara district (black circles $=$ water sampling sites; red circles $=$ fish sampling sites). 


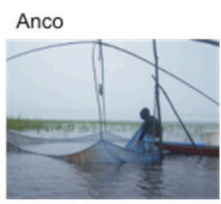

Bubu
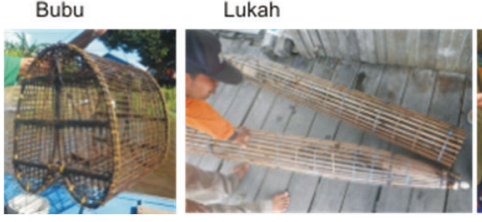

Rengge
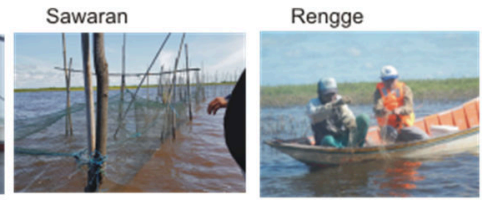

Tempirai

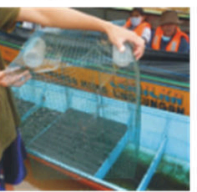

Rawai haruan

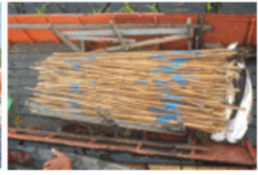

Bubu

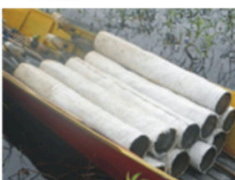

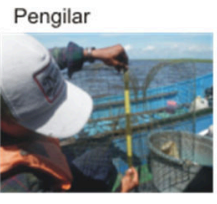

Tokong

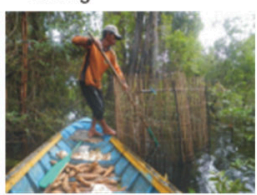

Fig. 2. Local fishing gears used for fish collection in the study locations in the middle Mahakam, Kutai Kartanegara district

\section{Results}

This part will present the study results concerning fish diversity, tabulations of fish species, the number of individuals found from lakes and streams/rivers, water velocities measured, and water quality.

\subsection{Fish fauna}

The study identified 50 fish species from the total number of 7,377 fish obtained from two locations: lakes and streams, which belonged to 19 families, eight orders, and two classes. Cyprinidae was the most abundant both in population and species (1,022 nd and 21 taxa), followed byBagridae (63 Ind. and five taxa), Channidae (53 Ind. and three taxa), Clariidae (10 Ind. and three taxa), Siluridae (403 Ind. and three taxa). At the same time, other families owned just one taxon. Fish species identified from the two studied locations are presented in the tables below. 
Table 1. The fish species for all gears and all periods from the lake of Semayang and Melintang in the middle Mahakam, Kutai Kartanegara district.

\begin{tabular}{|c|c|c|c|c|c|}
\hline No & Family & Species & Local name & No. Ind. & Weight (g) \\
\hline 1 & Cyprinidae & O. repang & Repang (Cyprinid) & 191 & 506.9 \\
\hline 2 & & C. apogone & Buin (Cyprinid) & 3 & 133.5 \\
\hline 3 & & C. enoplos & Buin/Repang & 22 & 175.5 \\
\hline 4 & & L. setigerum & Rasborapanj./Apollo (Cyprinid) & 2 & 13.7 \\
\hline 5 & & L. hoevenii & Jelawat (Cyprinid) & 2 & 157.1 \\
\hline 6 & & O. vittatus & Puyau/Nilem (Cyprinid) & 12 & 353.2 \\
\hline 7 & & P. gastroides & Alalang (Cyprinid) & 9 & 53.0 \\
\hline 8 & & B. schwanenfeldii & Salap (Cyprinid) & 30 & 238.1 \\
\hline 9 & & B. laevis & Berukung (Cyprinid) & 4 & 300.5 \\
\hline 10 & & L. festivus & Puyau/Nilem Panjang (Cyprinid) & 11 & 222.8 \\
\hline 11 & & L. trinema spp. & SeluangGaris (Cyprinid) & 12 & 20.0 \\
\hline 12 & & Rasbora spp. & Seluang (Cyprinid) & 126 & 72.4 \\
\hline 13 & & $R$. argyrotaenia & Seluang (A)(Cyprinid) & 12 & 45.7 \\
\hline 14 & & R. einthovenii & Seluang B (Cyprinid) & 24 & 40.0 \\
\hline 15 & & T. thynnoides & Kendia (Cyprinid) & 34 & 407.6 \\
\hline 16 & Bagridae & A. maculatus & Legok & 1 & 27.8 \\
\hline 17 & & M. singaringan & Kalibere & 3 & 76.3 \\
\hline 18 & Channidae & C. striata & Haruan/Gabus & 2 & 119.6 \\
\hline 19 & Siluridae & K. apogon & Bentilap & 1 & 143.4 \\
\hline 20 & Belontidae & T. pectoralis & Sepat Siam & 16 & 493.9 \\
\hline 21 & & T. trichopterus & Sepat Jawa & 3 & 17.1 \\
\hline 22 & Helostomatidae & H. temminckii & Biawan & 9 & 339.0 \\
\hline 23 & Anabantidae & A. testudineus & Betok/Pepuyu & 70 & 2391.3 \\
\hline 24 & Chiclidae & O. niloticus & Nila & 8 & 229.8 \\
\hline 25 & Engraulidae & Stolephorus sp. & Teri Kaca & 5050 & 596.0 \\
\hline 26 & Eleotrididae & O. marmorata & Betutu & 5 & 209.2 \\
\hline 27 & Loricariidae & L. pardalis & Ikan Cicak & 2 & 49.7 \\
\hline 28 & Mastacembelidae & M. maculates & Sili/Tilan & 1 & 66.0 \\
\hline 29 & Pristolepididae & P. fasciata & Ikan Tempe & 6 & 307.6 \\
\hline 30 & Soleidae & S. orientalis & IkanLidah & 2 & 64.5 \\
\hline
\end{tabular}

Notes: Enggelam Stream: black water small river entering Melintang Lake; Pela River: small river entering the mainstream of Mahakam coming from Semayang Lake; Siran Stream: black water small river entering Kedang Kepala River (tributary/branch of the mainstream).

Table 2. Fish species obtained from Enggelam Stream, Pela River and Siran Stream in the middle Mahakam, Kutai Kartanegara district.

\begin{tabular}{clllcc}
\hline No & Family & Species & Local name & No. Ind. & Weight \\
\hline 1 & Cyprinidae & O. repang & Repang (Cyprinid) & 16 & 766.9 \\
2 & C. armatus & Buin (Cyprinid) & 3 & 179.3 \\
3 & P. brevis & Rasbora (Cyprinid) & 10 & 7.5 \\
4 & P. endecanalis & Sumatra (Cyprinid) & 70 & 33.6 \\
5 & C. apogon & Gelagehrepang (Cyprinid) & 93 & 2540 \\
6 & L. setigerum & Rasborapanj./Apollo (Cyprinid) & 15 & 28.2 \\
7 & L. hoevenii & Jelawat (Cyprinid) & 10 & 5525 \\
8 & O. melanoptpleura & Kelabau (Cyprinid) & 8 & 888 \\
9 & O. triporos & Berukung (Cyprinid) & 169 & 860.2 \\
10 & P. gastroides & Alalang (Cyprinid) & 125 & 725.6 \\
11 & R. argyrotaenia & SusurBatang (Cyprinid) & 2 & 85.1 \\
12 & M. macrochirus & Parang-Parang (Cyprinid) & 1 & 32 \\
13 & B. schwanenfeldii & Salap (Cyprinid) & 1 & 212 \\
14 & B. laevis & Berukung (Cyprinid) & 1 & 19.9 \\
15 & Bagridae & M. pelaniceps & Kalibere (Catfish) & 16 & 654.4 \\
16 & M. nigriceps & Kalibere (Catfish) & 9 & 365 \\
17 & M. nemurus & Baung (Catfish) & 34 & 2327.2 \\
18 & Clariidae & C. batrachus & Lele (Catfish) & 2 & 87 \\
19 & C. nieuhofii & Keli (Catfish) & 7 & 419.1
\end{tabular}




\begin{tabular}{llllcc}
20 & Clarias sp. & LelePayang (Catfish) & 1 & 124.8 \\
21 & Channidae & C. lucius & Kesung/Haruan (Snakehead) & 3 & 253.1 \\
22 & C. micropeltes & Toman (Snakehead) & 2 & 517 \\
23 & & C. striata & Haruan (Snakehead) & 44 & 1443.2 \\
24 & Siluridae & K. macrocephalus & LaisKembang (Catfish) & 290 & 8649.7 \\
25 & & K. apogon & LaisHitam (Catfish) & 109 & 5768.6 \\
26 & & O. bimaculatus & Sepat Siam (Gourami) & 7 & 311 \\
27 & Belontidae & T. pectoralis & Sepat Jawa (Gourami) & 106 & 1717.6 \\
28 & & B. trichopterus & Belida (bronze featherback) & 167 & 97 \\
29 & Notopteridae & N. borneensis & Patin (Shark catfish) & 2055.6 \\
30 & Helostomatidae & H. temminckii & Pepuyu Climbing perch) & 281 & 2297.1 \\
31 & Pangasiidae & P. pangasius & Belut (Swamp eel) & 74 & 93.9 \\
32 & Anabantidae & A. testudineus & Kuyur (giant devil catfish) & 8 & 218.2 \\
33 & Synbranchidae & M. albus & Nila (Nile tilapia) & 1 & 129.5 \\
34 & Sisoridae & B. syarelli & & 3 & 1211.0 \\
35 & Chiclidae & O. niloticus & & 1704 & 42543.3 \\
\hline
\end{tabular}

Notes: Enggelam Stream: black water small river entering Melintang Lake; Pela River: small river entering the mainstream of Mahakam coming from Semayang Lake; Siran Stream: black water small river entering Kedang Kepala River (tributary/branch of the mainstream).

Table 3. Results of the water velocities and water depths measurement in the middle Mahakam, Kutai Kartanegara district.

\begin{tabular}{|c|c|c|c|c|c|}
\hline \multirow{2}{*}{ No } & \multirow{2}{*}{ Sites measured } & \multicolumn{2}{|c|}{ Lat/Long } & \multirow{2}{*}{ Depth (m) } & \multirow{2}{*}{$\begin{array}{l}\text { Velocity } \\
(\mathrm{m} / \mathrm{sec})\end{array}$} \\
\hline & & Lat. & Long. & & \\
\hline 1 & Semayang lake & $0^{\circ} 14^{\prime} 38.6^{\prime \prime}$ & $116^{\circ} 29^{\prime} 09.5^{\prime \prime}$ & 1.9 & 0.1 \\
\hline 2 & Melintang lake & $0^{\circ} 15^{\prime} 06.3^{\prime \prime}$ & $116^{\circ} 20^{\prime} 15.6^{\prime \prime}$ & 3.4 & 0.1 \\
\hline 3 & Melintang lake & $0^{\circ} 14^{\prime} 38.5^{\prime \prime}$ & $116^{\circ} 20^{\prime} 18.0^{\prime \prime}$ & 1.1 & 0.1 \\
\hline 4 & Semayang lake & $0^{\circ} 14^{\prime} 43.5^{\prime \prime}$ & $116^{\circ} 31^{\prime} 55.5^{\prime \prime}$ & 2.3 & 0.1 \\
\hline 5 & Semayang lake & $0^{\circ} 15^{\prime} 18.9^{\prime \prime}$ & $116^{\circ} 30^{\prime} 37.8^{\prime \prime}$ & 1.4 & 0.3 \\
\hline 6 & Siran lake & $0^{\circ} 04^{\prime} 08.9^{\prime \prime}$ & $116^{\circ} 35^{\prime} 01.5^{\prime \prime}$ & 2.7 & 0.3 \\
\hline 7 & Siran lake & $0^{\circ} 05^{\prime} 06.5^{\prime \prime}$ & $116^{\circ} 35^{\prime} 55.6^{\prime \prime}$ & 2.1 & ND \\
\hline 8 & Siran lake & $0^{\circ} 02^{\prime} 19.9^{\prime \prime}$ & $116^{\circ} 33^{\prime} 37.1^{\prime \prime}$ & 2.4 & ND \\
\hline 9 & Enggelam stream & $0^{\circ} 13^{\prime} 59.2^{\prime \prime}$ & $116^{\circ} 18^{\prime} 48.4^{\prime \prime}$ & 2.2 & 0.5 \\
\hline 10 & Enggelam stream & $0^{\circ} 14^{\prime} 58.4^{\prime \prime}$ & $116^{\circ} 20^{\prime} 07.6^{\prime \prime}$ & 4.0 & 0.4 \\
\hline 11 & Enggelam stream & $0^{\circ} 08^{\prime} 53.3^{\prime \prime}$ & $116^{\circ} 14^{\prime} 18.0^{\prime \prime}$ & 4.1 & 0.4 \\
\hline 12 & Enggelam stream & $0^{\circ} 13^{\prime} 59.1^{\prime \prime}$ & $116^{\circ} 18^{\prime} 48.6^{\prime \prime}$ & 2.1 & 0.5 \\
\hline 13 & Melintang stream & $0^{\circ} 17^{\prime} 05.8^{\prime \prime}$ & $116^{\circ} 24^{\prime} 23.4^{\prime \prime}$ & 4.2 & 0.3 \\
\hline 14 & Pela river & $0^{\circ} 14^{\prime} 18.5^{\prime \prime}$ & $116^{\circ} 33^{\prime} 16.5^{\prime \prime}$ & 3.6 & 0.3 \\
\hline 15 & Pela iver & $0^{\circ} 14^{\prime} 14.7^{\prime \prime}$ & $116^{\circ} 34^{\prime} 00.8^{\prime \prime}$ & 1.6 & 0.4 \\
\hline 16 & Pela river & $0^{\circ} 14^{\prime} 18.7^{\prime \prime}$ & $116^{\circ} 33^{\prime} 16.6^{\prime \prime}$ & 3.6 & 0.5 \\
\hline 17 & Pela river & $0^{\circ} 14^{\prime} 14.1^{\prime \prime}$ & $116^{\circ} 33^{\prime} 39.2^{\prime \prime}$ & 3.5 & 0.59 \\
\hline 18 & Siran stream & $0^{\circ} 07^{\prime} 17.4^{\prime \prime}$ & $116^{\circ} 37^{\prime} 48.9^{\prime \prime}$ & 3.4 & 0.48 \\
\hline 19 & Mahakam river & $0^{\circ} 14^{\prime} 09.0^{\prime \prime}$ & $116^{\circ} 34^{\prime} 07.2^{\prime \prime}$ & 1.7 & 0.37 \\
\hline 20 & Mahakam river & $0^{\circ} 08^{\prime} 49.8^{\prime \prime}$ & $116^{\circ} 40^{\prime} 46.3^{\prime \prime}$ & 4.5 & 0.46 \\
\hline 21 & Ked kepala river & $0^{\circ} 07^{\prime} 47.0^{\prime \prime}$ & $116^{\circ} 38^{\prime} 24.0^{\prime \prime}$ & 6.8 & 0.69 \\
\hline 22 & Enggel. swamp & $0^{\circ} 14^{\prime} 00.7^{\prime \prime}$ & $116^{\circ} 18^{\prime} 47.1^{\prime \prime}$ & 1.2 & ND \\
\hline
\end{tabular}

\subsection{Aquatic environmental conditions}

Throughout the study, the analysis of water quality parameters in the laboratory resulted in the concentrations of DO ranging from 2.7 to $5.9 \mathrm{mg} / \mathrm{L}$. In most sampling sites were within the tolerable range (standard limit: $4 \mathrm{mg} / \mathrm{L}$ ).; water $\mathrm{pH}$ ranged between 4.0 and 7.3 (standard limit: $4.0 \mathrm{mg} / \mathrm{L}$ ); $\mathrm{PO}_{4}-\mathrm{P}$ ranged from 0.01 to $0.09 \mathrm{mg} / \mathrm{L}$ (standard limit: 0.2 $\mathrm{mg} / \mathrm{L}$ ); $\mathrm{NO}_{3}-\mathrm{N}$ ranged from 0.05 to $0.17 \mathrm{mg} / \mathrm{L}$ (standard limit: $10 \mathrm{mg} / \mathrm{L}$ ); $\mathrm{NO}_{2}-\mathrm{N}$ ranged from 0.008 to $0.041 \mathrm{mg} / \mathrm{L}$ (standard limit: $0.06 \mathrm{mg} / \mathrm{L}$; [26]; $\mathrm{NH}_{3}-\mathrm{N}$ ammonia ranged from 
0.02 to $0.23 \mathrm{mg} / \mathrm{L}$ (standard limit: $<0.5 \mathrm{mg} / \mathrm{L}, \mathrm{BOD}_{5}$ ranged from 1.0 to $2.2 \mathrm{mg} / \mathrm{L}$ standard limit: $3.0 \mathrm{mg} / \mathrm{L}$ ): COD ranged from 10.2 to 93.9 , most sampling sites exceeded standard limit, $25.0 \mathrm{mg} / \mathrm{L} ; \mathrm{H}_{2} \mathrm{~S}$ ranged from 0.01 to $0.60 \mathrm{mg} / \mathrm{L}$, all sampling sites exceeded the standard limit, $0.002 \mathrm{mg} / \mathrm{L}$. Sixteen (16) heavy metals were investigated, 13 metals were below the detection limit, while others were found to exceed the standard limit, such iron (Fe) was from 0.33 to $1.48 \mathrm{mg} / \mathrm{L}$, all sampling sites were above the standard limit $(0.30$ $\mathrm{mg} / \mathrm{L}$ ). Globally, guidelines indicating the concentration of physic-chemical parameters and level of heavy metals refer to the regulation of Local Government of East Kalimantan No.: 02 the Year 2011 besides the Government Republic of Indonesia No.: 82 the Year 2001).

\section{Discussion}

In the lake, we found large species of Cyprinidae representing $50 \%$ or 15 species of the total 30 species recognized in the study. According to [21], this family has the highest diversity in species, various morphological and behavioral properties, and a wide range of habitat requirements. Like in the lake, in-stream cyprinids were also observed as the majority representing $40 \%$ or 14 species of the total 35 species during the study (Table 2). Based on the data of the number of individuals and the species identified from all fishing gears and all periods from each ecosystem (Table 2 and 3), the diversity index values were calculated, and the results are in the following table.

Table 4. Values of the diversity index of fish fauna from all fishing gears and all periods based on location (lakes and streams) in the middle Mahakam, Kutai Kartanegara district.

\begin{tabular}{lrrccc}
\hline & \multicolumn{2}{c}{ Ecosystem } & \multicolumn{2}{c}{ Field remarks } \\
\cline { 2 - 6 } & Lake & Stream & Location & \# site & No.of species \\
\hline Taxa_S & 30 & 35 & Semaang lake & 3 & 15 \\
Individuals & 5673 & 1704 & Melintang lake & 4 & 15 \\
Shannon_H & 0.606 & 2.632 & Enggelam stream & 4 & 26 \\
Dominance_D & 0.794 & 0.097 & Siran stream & 1 & 7 \\
Evenness_e^ $\mathrm{H} / \mathrm{S}$ & 0.061 & 0.397 & Pela river & 1 & 9 \\
Margalef & 3.355 & 4.569 & Kedang Kepala river & 1 & 6 \\
\hline
\end{tabular}

In streams, we found more fish fauna and the reasons as reported by [22] that stream has environmental characteristics such as macrophytes, food availability, and habitat heterogeneity. They influence the distribution of freshwater fish. In addition, [23] reported the species richness of river fish with hydrology attributes positively correlated to the depth of water affecting DO concentration and $\mathrm{pH}$ to determine the fish gathering, and [24] found species richness varied directly with ambient oxygen and alkalinity.

Our study measured water velocities and water depths in lakes and streams. In lake, velocities ranged from 0 (not detected/ND) to $0.30 \mathrm{~m} / \mathrm{s}$; water depths from 1.2 to $2.7 \mathrm{~m}$; while in stream, velocities ranged from 0.3 to $0.69 \mathrm{~m} / \mathrm{s}$; water depths from 1.6 to $6.8 \mathrm{~m}$ (Table 3, above). Commonly, fish species can live in various places, but they occupy a particular place. [25] caught 1,223 fishes of seven species in four rivers with different depths. $70 \%$ of the fishes were caught from rivers with a depth of $<4 \mathrm{~m}$. In Ghana, the threat of fish life is caused by low dissolved oxygen with $0.7 \mathrm{mg} / \mathrm{L}$, which affects the abundance of organic materials [26].

We rated the number of fish caught from each fishing gear, and we obtained the mean catch as CPUE, as is shown in Table 5 below. The table informs that Anco and Sawaran produced the most fish, $945.8 \mathrm{Ind} . / \mathrm{hr}$ and $287.7 \mathrm{Ind} . / \mathrm{hr}$ respectively, while others ranged only between 0.4 and $25.3 \mathrm{Ind} . / \mathrm{hr}$. 
Table 5. CPUE of different fishing gears used during the study in the middle of Mahakam, Kutai Kartanegara, East Kalimantan.

\begin{tabular}{|c|c|c|c|c|c|c|c|c|}
\hline \multirow[b]{2}{*}{ No } & \multirow[b]{2}{*}{$\begin{array}{l}\text { Type of } \\
\text { gear }\end{array}$} & \multirow{2}{*}{$\begin{array}{l}\text { Fish. } \\
\text { Time } \\
\text { (hr) }\end{array}$} & \multirow{2}{*}{$\begin{array}{l}\text { Total } \\
\text { weight }\end{array}$} & \multirow{2}{*}{$\begin{array}{l}\text { Total } \\
\text { ind. }\end{array}$} & \multicolumn{2}{|l|}{ CPUE } & \multirow[b]{2}{*}{$\begin{array}{l}\text { No.of } \\
\text { active }\end{array}$} & \multirow[b]{2}{*}{ Location } \\
\hline & & & & & $\mathrm{g} / \mathrm{hr}$ & $\begin{array}{l}\text { (ind } \\
/ \mathrm{hr}\end{array}$ & & \\
\hline 1 & Anco & 4 & 5000.0 & 3783.0 & 1250.0 & 945.8 & 1 & Lake \\
\hline 2 & Sawaran & 192 & 77866.5 & 55245.0 & 405.6 & 287.7 & 4 & Lake \\
\hline 3 & Pengilar & 120 & 22148.2 & 3032.0 & 184.6 & 25.3 & 2 & L. and riv \\
\hline 4 & Tempirai & 96 & 41808.5 & 2060.0 & 871.0 & 21.5 & 2 & River \\
\hline 5 & Rengge & 46 & 46350.0 & 781.0 & 1007.6 & 16.9 & 5 & River \\
\hline 6 & Lukah & 96 & 21213.6 & 351.0 & 220.9 & 3.7 & 2 & River \\
\hline 7 & Rawai (h) & 20 & 6082.7 & 26.0 & 304.1 & 1.3 & 1 & River \\
\hline 8 & Tokong & 20 & 4900.0 & 8.0 & 245.0 & 0.4 & 1 & River \\
\hline
\end{tabular}

Notes: Fish. $=$ fishing; activ $=$ activities

Since a long time ago, local fishers have used Anco and Sawaran are intended to provide fish food to feed fish cultured in floating cages such as Common/striped snakehead (Gabus), Giant snakehead (Toman), Catfish (Lele), and Shark catfish (Patin). In general, the catch of the two gears consisted of juveniles and small fish from various important species with high economic value. According to fish farmers, they feed $5.0 \mathrm{~kg} /$ day for one floating cage, or $150.0 \mathrm{~kg} /$ month, or $1,850 \mathrm{~kg} /$ year or $185,000 \mathrm{small}$ fish/cage/year. In terms of sustainable fisheries, the juvenile fish, otherwise the small fish, plays a significant role in the regeneration of the fisheries sector. Thus, they are to be protected from any not ecofriendly fishing gear and any unselective fishing. [27] ensure us that over-fishing causes changes in the stock structure of individual species and direct or indirect changes in the fish communities in an ecosystem. In other words, the two gears (Anco and Sawaran) must be prohibited operated in the middle of Mahakam in general and in lakes in particular.

\section{Conclusion}

The present study recovered 50 species, the fish fauna found in peatland water or black water and a stream and the lake. The study recognized two species: Long pectoral-fin minnow Macrochirichthys macrochirus and Goonch Bagarius yarelli have been listed in the IUCN Red List of Threatened Species published in 2019 and 2020. Anco or lift net and sawaran or trap net was considered as unselective fishing gear and un-ecological friendly gear. Physical and chemical environmental conditions of black water of peatland were observed differently with water conditions in lakes. The concentration of $\mathrm{H}_{2} \mathrm{~S}, \mathrm{NO}_{2}-\mathrm{N}$, and heavy metal iron/Fe level was significantly over the allowable limit for all sampling sites, and others were mainly within the standard limit.

\section{Acknowledgements}

The authors express gratitude to the University of Mulawarman and the Faculty of Fisheries and Marine Science for supporting the facilities during data analysis. Special thank goes to GIZ (Deutsche Gesellschaft für Internationale Zusammenarbeit) East Kalimantan for the collaboration and financial support; Hydrography and Water Quality Laboratory of Mulawarman University and local people who assist during the study 


\section{References}

1. E.B.P. de Jong, M.J. Ragas, G. Nooteboom, M. Mursidi, Wetlands 35, 733-744 (2015)

2. U. Chokkalingam, I. Kurniawan, Y. Ruchiat, J.Eco.Socie. 10, 1 (2005)

3. J.O. Rieley, S.E. Page, S.H. Limin, S. Winarti, The peatland resource of Indonesia and the Kalimantan Peat swamp forest research project (Samara Publishing, Cardigan, 1997)

4. World Wide Fund For Nature, Borneo: treasure island at risk (WWF Germany, Frankfurt am Main, 2005)

5. F.A. Buschman, A.J.F. Hoitink, S.M. de Jong, P. Hoekstra, H.Hidayat, M.G. Sassi. Hydrol. Earth Syst. Sci. 8 (2011)

6. L. Porter-Bolland, E.A. Ellis, M.R. Guariguata, I. Ruiz-Mallén, S.Yegrete Yankelevich, V. Reyes-García, FEM 268 (2011)

7. K. Obidzinski, R. Andriani, H. Komarudin, A. Andrianto. CIFOR Indonesia. Ecology and Society 17, 1 (2012)

8. J.Y. Zhang, C.G. Zheng, D.Y. Ren, C. L. Chou, J. Liu, R.-S. Zeng, Z.P. Wang, F.H. Zhao, Y.T. Ge, J. Fuel 83 (2004)

9. I. Suyatna, Sulistyawati, Adnan, M. Syahrir, Ghitarina, Abdunnur, S. Saleh, J. AACL Bioflux 10, 5 (2017)

10. M. Mustakim, I. Suyatna, A. Rafii, S.A. Samson, Ikan natif dan endemik Indonesia biologi, konservasi dan pemanfaatan (Bandar Publishing, Banda Aceh, 2020)

11. M.S. Christensen, Int. Rev. Hydrobiol. 77, 593-608 (1992)

12. M. Kottelat, J. Trop Biodiv 2, 3 (1995)

13. M. Kottelat, A.J. Whitten, S.N. Kartikasari, S. Wiryoatmodjo (Periplus Edition, Halifax, 1992)

14. G. Allen, Marine fishes of South-East Asia (Periplus, Singapore, 2000)

15. T. Peristiwadi, Economically important marine fish in Indonesia (identification clue) (in Bahasa Indonesia) (LIPI Press, Jakarta, 2006)

16. H. Masuda, C. Araga, T. Yoshiro, Coastal fishes of Southern Japan (Tokai Univ. Press, Tokyo, 1975)

17. I. Suyatna, A.A. Bratawinata, A.S. Sidik, A. Ruchaemi, J.Biodiv. 11, 4 (2010)

18. I. Suyatna I, Mislan, A. Rahman, A.Winata, Y.I. Wijaya, J.Biodiv. 18, 2 (2017)

19. I. Suyatna, M. Syahrir, Mislan, Y.I. Wijaya, Abdunnur, J.Omni. 13, 2 (2017)

20. O. Hammer, PAST Version, 3, 23 (2006)

21. M.B. Bain, J. Appl. Ichthyol. 27, 3 (2011)

22. R.F. Menezes, F. Borchsenius, J.C. Svenning, M. Søndergaard, T.L. Lauridsen, F. Landkildehus, E. Jeppesen, Hydrobiologia 710, 1 (2013)

23. W.S. Lakra, U.K. Sarkar, R.S. Kumar, A. Pandey, V.K. Dubey, O.P.Gusain, J. Envi. 30, 306-319 (2010)

24. F.W.H. Beamish, P. Sa-ardrit, S. Tongnunui, J. Envi. Biol. Fish 76, 237-253 (2006)

25. M.R. Costa, T.M. Mattos, J.L. Borges, F.G. Araújo, J. Neo Ich. 11 (2006)

26. E.L. Olalekan, F. Kies, L.A.A. Omolara, S.D. Rashidat, F.B. Hakeem, A.S. 
Latunji, A.A. Zaid, N. Emeka, O.I. Charles, F. Oluwaseun, J. EAT 5 (2015)

27. M.L. Bari, The Royal Inst of Tech Stockholm (2015) 